\title{
Compressed Stabilized Mud Block using Alccofine and Sodium Meta Silicate
}

\author{
Vinod B R ${ }^{* 1}$, Shobha R ${ }^{1}$, Vikas $C^{2}$, Praveen Kumar D S ${ }^{2}$, Darshan $\mathbf{J}^{2}$, Bhuvanesh $\mathrm{G}^{2}$ \\ ${ }^{I}$ Assistant Professor, Civil Engineering, BMS Institute of Technology \& Management, Yelahanka, Bengaluru, Karnataka, India. \\ ${ }^{2} U G$ Student, Civil Engineering, BMS Institute of Technology \& Management, Yelahanka, Bengaluru, Karnataka, India.
}

\begin{abstract}
This paper presents the tests that are carried on soil using stabilizers in manufacturing stabilized mud block. Stabilization of mud blocks are also called as compressed earth block it is a building material made from damp soil which are later compressed at high pressure, and made into blocks. Main material used in preparing the stabilized mud blocks is the soil. Using soil as main material and adding stabilizers to the soil such as Alccofine (pozzolanic materials) and Sodium meta silicate. Basic tests were carried out as Specific gravity, liquid limit, plastic limit, regular proctor test, Unconfined compression test with a maximum load of $43.5 \mathrm{KN}$ and are held for $0,3,7$ days. In order to find out the Optimum Moisture Content (OMC), Maximum Dry Density (MDD) and compression strength, three samples were made by adding the proportions as 1.96 percentage red soils with 4 percentage Alccofine, 2. 97 percentage Red soil with 3 percentage sodium meta silicate and 3.93 percentage Red soil with both 4 percentage Alccofine and 3 percentage sodium meta silicate. As the days of curing increases the compressive strength of the blocks increases.
\end{abstract}

Keywords - Red Soil; Alccofine; Sodium Meta Silicate; Maximum Moisture Content; Maximum Dry Density; Compressive Strength; Stabilized Mud Blocks.

\section{Introduction}

Soil can be used as building material in the form of a mud, adobe and it can even be used as burnt bricks. This soil can be used to construct a heavy infrastructure building. Soil is used as a construction material for centuries. Using mud as construction material as it is easily accessible, economical and even environmentally friendly material. Mud is available in majority of the places. Use of mud block increases the strength efficiency and it is cost efficient when compared to the concrete and bricks. The main drawbacks to using mud blocks in building are their thickness, they lose strength in saturation and erosion due to the effect to rain on the walls of the mud [1].

There are alternative materials for construction purposes such as natural stone, cement concrete hollow blocks, etc. In this alternative materials soil cement blocks are used as ideal construction materials which can be useful for low cost housing properties which are taken by government under numerous housing schemes for upbringing of common man, see [2]. Earth has always been and has been the most commonly used building material in India as distinct from its own culture. The design of mud walls typically varies greatly from the topography, climatic conditions and needs of different regions. The cob, wattle, daub, rammed earth, and adobe are the traditional methods that can be used for earth construction. Around 55 per cent of the houses built in India use raw earth for wall construction [3]. By using soil stabilization, we can reduce the damage on the mud blocks which we consider as the drawbacks of mud walls. Advantages of using compressed earth block in the building industry may include quality of resources, economy, fire resistance, favourable climatic conditions, and less energy consumption. Although its disadvantages include low resilience, low tensile strength, low resistance to impact, low resistance to abrasion and low acceptability. The most important advantage of using a compact block of earth is that they have low energy consumption. Such mud blocks usually need 10 percent or less of the energy required to produce equivalent fired clay bricks and concrete masonry units, see [4].

Problems that can occur with the use of such building materials include low tensile strength, brittle behaviour and water corrosion. To improve water resistance and strength we can use waste materials like Alccofine, sodium meta silicate and combination of these both can undoubtedly improve the properties. Stabilizers used in this project are allcofine and sodium meta silicate [5]. We can produce these stabilized mud blocks without any of the professional labour and sophisticated machinery. Mud blocks have a significantly lower compression power than traditional bricks [6].

\section{Research Phases}

- Collection of soil sample.

- Collection of stabilizers.

- Preparation of block.

- Preparation of soil sample and testing.

- Mixing of stabilizers in soil.

- Casting samples and air curing. (number of curing days $0,3,7)$ 
- Testing of air cured samples and compression strength test.

\section{Materials}

\subsection{Red Soil}

Soil is collected from Major Sandeep Unnikrishnan road, near dairy circle, Bangalore, Karnataka. Soil which is easily available in the locality and can be used as a manufacturing of mud has been selected for this project. Their physical property and the test values are shown in Table-1, testes has been conducted as per IS 2920, IS 2720 and confined as per IS 1725.1982.

Table-1 Physical Properties of Red Soil

\begin{tabular}{|c|l|l|}
\hline Sl.No & \multicolumn{1}{|c|}{ Properties } & Values \\
\hline 1 & Specific Gravity & 2.6 \\
\hline 2 & Colour & Red \\
\hline 3 & Liquid Limit (\%) & 70 \\
\hline 4 & Plastic Limit (\%) & 40 \\
\hline 5 & Optimum Moisture Content (\%) & 15 \\
\hline 6 & Maximum Dry Density (g/cc) & 1.6 \\
\hline 7 & Cohesion (c) (kpa) & 51 \\
\hline 8 & Angle of friction $(\varnothing)$ & 39 \\
\hline
\end{tabular}

Alccofine: A micro-fine substance that varies from cement, fly ash, and silica. Alccofine particle size is much smaller than the aforementioned particles. That is manufactured in India. Because of its optimized particle size distribution, Alccofine has unique features for enlarging 'concrete output' in both fresh and hardened stages. This stabilizer can also be used as a functional substitute for silica fume since it has an ideal distribution of particle size not too coarse, not too finer.

Table-2 Chemical Properties of Alccofine

\begin{tabular}{|c|c|c|c|c|c|c|}
\hline $\mathrm{Cl}$ & $\mathrm{MgO}$ & $\mathrm{Fe}_{2} \mathrm{O}_{3}$ & $\mathrm{Al}_{2} \mathrm{O}_{3}$ & $\mathrm{SO}_{3}$ & $\mathrm{SiO}_{2}$ & $\mathrm{CaO}$ \\
\hline $0.03-0.05$ & $0.8-1.4$ & $3.8-4.4$ & $5-5.6$ & $2-2.4$ & $21-23$ & $61-34$ \\
\hline
\end{tabular}

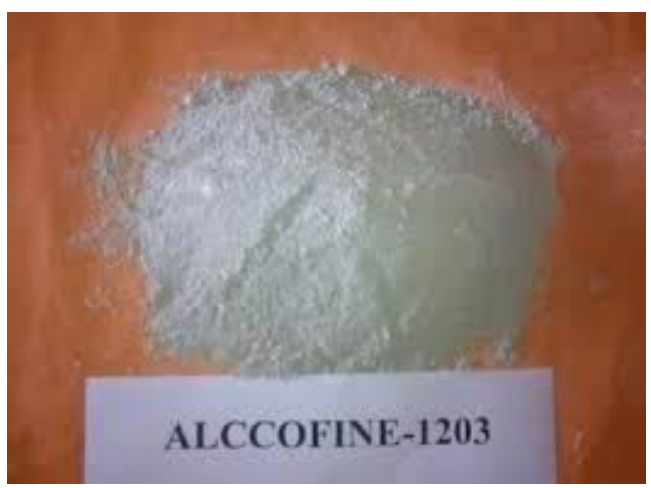

Fig.1: Alccofine

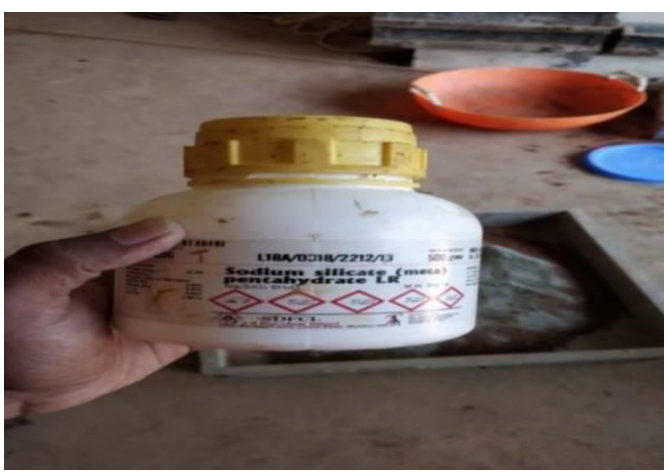

Fig. 2: Sodium Meta Silicate

Sodium Meta Silicate: It is a chemical component which has a $\mathrm{Na} 2 \mathrm{SiO} 3$ formula. It is an ionic compound consisting of $[\mathrm{Na}+]$ sodium cations and [SiO3-] polymeric meta silicate anion. These sodium meta silicate can increase strength and durability of sandy soils; however, there is no field evidence that its use in the stabilized material in construction is subjected to the freezing and thawing cycles due to the cold temperature. With or without addition of precipitants in sodium meta silicate are of a few values in dust proofing or waterproofing.

Chemical Properties Of Sodium Meta Silicagte is, Silicon dioxide $\mathrm{SiO}_{2}$ with Sodium oxide $\mathrm{Na}_{2} \mathrm{O}$

\subsection{Soil Sample Collection}

The soil sample used for the project is obtained from the construction of flyover at Major Sandeep Unnikrishnan Avenue, near Milky Circle, Bangalore, Karnataka. The soils transported in plastic gunny bag. The collected soil is been tested for basic engineering properties.

The basic testes conducted for the soil are:

- Specific Gravity

- Liquid Limit

- Plastic limit

- Standard Proctor compaction test

- Unconfined Compression Strength

\subsection{Collection of Stabilizers}

Soil stabilisation is a soil alternation to improve its physical properties. When using these stabilizers and also regulating the shrink swell properties, the strength of the soil can be improved, thereby increasing the load-bearing ability of a soil, and supporting pavements and foundations can also be beneficial. Cement, fly ash, lime fly ash, bitumen, tree resin some of the chemicals, Alccofine and ionic stabilizers of the soil stabilizers. For this project the soil stabilizers chosen are Alccofine and sodium meta silicate which is a chemical. 


\subsection{Preparation of Block}

For this project mould is used to cast the soil sample. The size of the mould is $15 \mathrm{~cm} \times 15 \mathrm{~cm} \times 15 \mathrm{~cm}$. The preparation of mould is done by bolting the mould the mould plates and connects to the base plat to form a cube. The oil is applied to the inner portion of the mould such that it prevents the soil sticking to the mould.

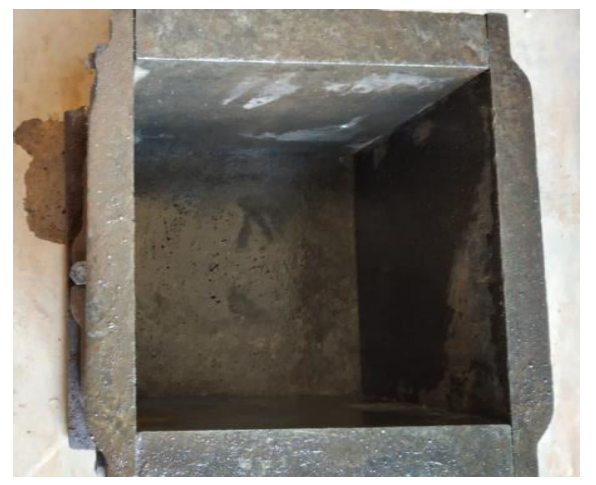

Fig. 3: Mould

Table 3: Dimension of the Mould

\begin{tabular}{|c|c|c|}
\hline 1 & Height & $150 \mathrm{~mm}$ \\
\hline 2 & Length & $150 \mathrm{~mm}$ \\
\hline 3 & Breadth & $150 \mathrm{~mm}$ \\
\hline
\end{tabular}

\subsection{Preparation of Soil Sample and Testing}

To prepare the sample, soil is being weighed and water is also taken. The soil required for one mould is $6.025 \mathrm{~kg}$. The optimum moisture content is 15 percent from moderate compaction. The needed water is 15 percent of the soil's total weight which will be equivalent to 0.9 litres. After weighing soil and water, mix thoroughly both soil and water. The mixture is transferred into the mould in three layers. Scratching is performed after every layer to obtain bonding between the layers. Each layer is 5 centimetres. Each layer is of $5 \mathrm{~cm}$. After compaction, the sample is removed from the mould and laid on the testing machine. Loading of $0.02 \mathrm{kN} / \mathrm{s}$ is applied on the sample. Horizontal and vertical strain readings for every $0.5 \mathrm{kN}$ is noted.

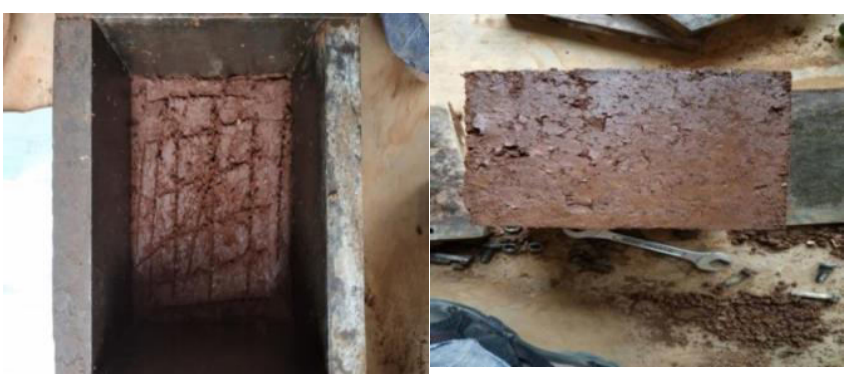

Fig. 4: Scratching and Soil Sample Preparation
Table 4: Method of Compaction

\begin{tabular}{|l|c|}
\hline \multicolumn{1}{|c|}{ No of layers } & $\mathbf{3}$ \\
\hline Each layer & $50 \mathrm{~mm}$ \\
\hline Total weight of soil & $6.075 \mathrm{~kg}$ \\
\hline Weight of soil in each layer & $2.025 \mathrm{~kg}$ \\
\hline Rate of loading & $20 \mathrm{~N} / \mathrm{s}$ \\
\hline Density & $1.8 \mathrm{~g} / \mathrm{cc}$ \\
\hline
\end{tabular}

\subsection{Mixing of Stabilizers In Soil}

After testing of soil samples, to sustain more loads the stabilizers are added to the soil. Alccofine and sodium meta silicate are added with a percentage of $4 \%$ and $3 \%$ respectively. Firstly, take soil weighing of $5.7 \mathrm{~kg}$, add aloccfine of $240 \mathrm{gm}$, and then add water of $900 \mathrm{ml}$. Mix it thoroughly, place the sample in the mould in three layers, each layer of size $5 \mathrm{~cm}$ and compacted likewise. Later the compression test, horizontal and vertical deformation tests are conducted and their values are noted.

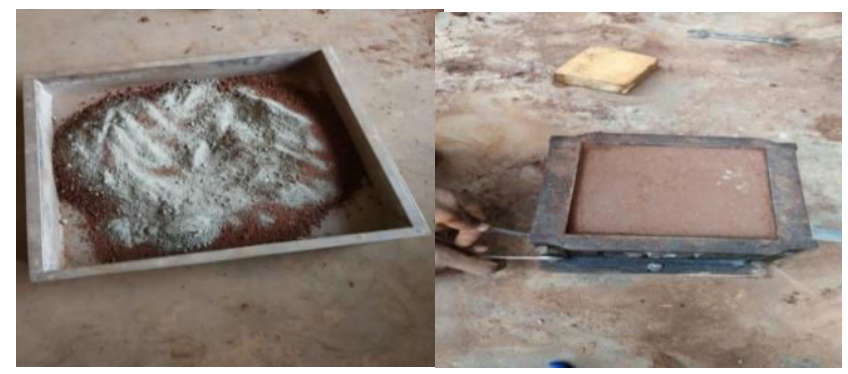

Fig. 5: Soil Plus Alccofine Mixing and its Sample

In the second sample we add soil weighing of $5.8 \mathrm{~kg}$, sodium meta silicate of $180 \mathrm{gm}$ is taken and then this sodium meta silicate is dissolved in water of $900 \mathrm{ml}$, then mixed with the soil. Upon careful mixing, the mixture is transferred to the mould in three layers, each layer being compacted and each layer being $5 \mathrm{~cm}$ in thickness. Later the compression test, horizontal and vertical deformation tests are conducted and their values are noted.

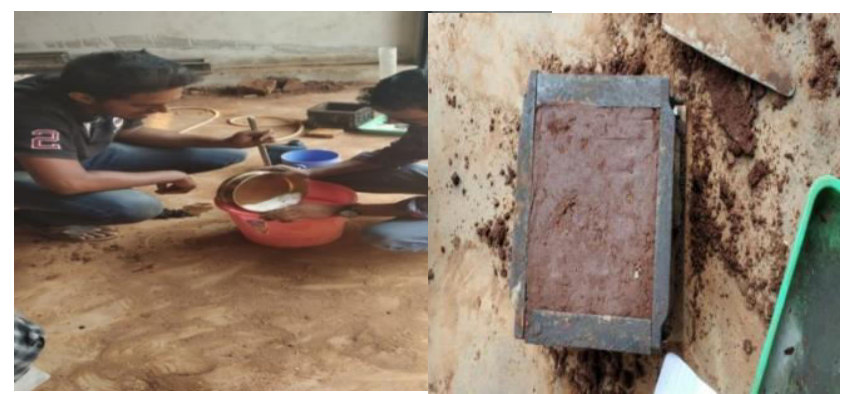

Fig. 6: Red Soil and Sodium Meta Silicate Mixing and its Sample

Finally, both the stabilizers have been mixed with the soil. First sodium meta silicate of $180 \mathrm{gm}$ is dissolved in water of $900 \mathrm{ml}$, then Alccofine of $240 \mathrm{gm}$ is added to the 
soil of weighing $5.6 \mathrm{~kg}$. Upon careful mixing, the mixture is transferred to the mould in three layers, each layer being compacted and each layer being $5 \mathrm{~cm}$ in thickness. Later the compression test, horizontal and vertical deformation tests are conducted and their values are noted.

\subsection{Casting Samples and Air Curing}

Alccofine as it is a fine cement material; it grains strength as the number of days increases. So the samples were casted and cured for 3 days and 7days. Soil and Alccofine sample each of 3days and 7days were casted. Totally 8 cubes were casted and cured. Even soil and sodium meta silicate were coted and cured for 3 days and 7 days. Also, three combinations of soil, Alccofine, sodium meta silicate with water were also casted for 3 days and 7 days. All these casted cubes were kept in open air space for air curing. Totally 24 cubes were casted for all combinations.

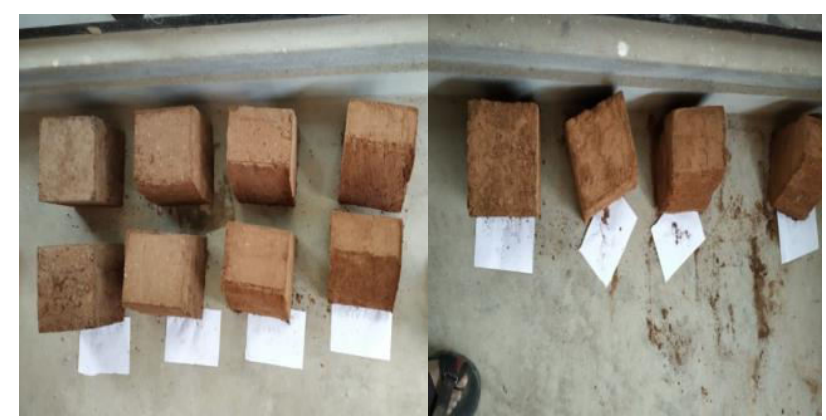

Fig. 7: Blocks Casted and Air Curing

After curing the samples were tested. 3 days samples were tested on third day and 7 days samples are tested on the $7^{\text {th }}$ day. The samples were tested in compression testing machine and strain gauges of horizontal and vertical are fixed. For every $500 \mathrm{~N}$ load and strain readings were noted.

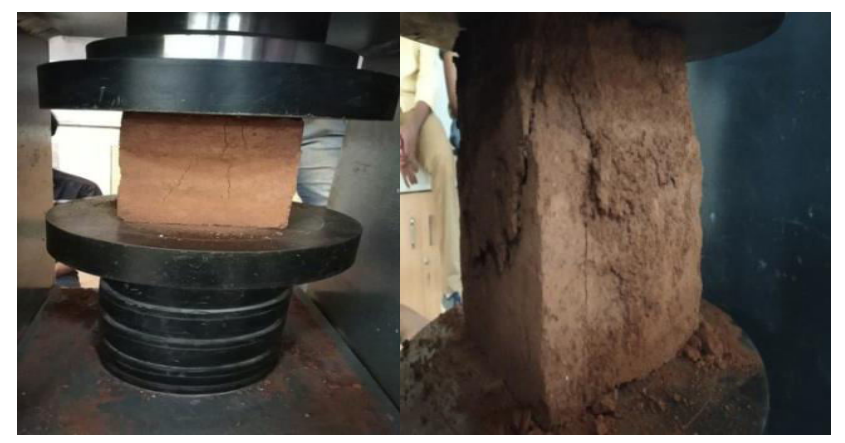

Fig. 8: Testing of Air Cured Samples

\section{Results and Discussion}

Compression test was conducted on bricks and corresponding horizontal and vertical deformation was determined. For different combinations of soil, Alccofine, sodium meta silicate were tested in compression testing machine and strain gauges of horizontal and vertical are fixed to all the three samples. For every $0.5 \mathrm{kN}$ load and strain readings were noted.

Type 1: Soil (96\%) + Alccofine (4\%)

Table 5: Results of Unconfinned Compression Test using Soil 96\% with Alccofine 4\%

\begin{tabular}{|c|c|c|c|c|}
\hline Block Size & $\begin{array}{c}\text { Period } \\
\text { of } \\
\text { curing }\end{array}$ & $\begin{array}{c}\text { Compress } \\
\text { ive } \\
\text { Strength } \\
\left(\mathrm{kN} / \mathrm{mm}^{2}\right)\end{array}$ & $\begin{array}{c}\text { Horizont } \\
\text { al } \\
\text { Deforma } \\
\text { tion } \\
(\mathrm{mm})\end{array}$ & $\begin{array}{c}\text { Vertical } \\
\text { Deformat } \\
\text { ion }(\mathrm{mm})\end{array}$ \\
\hline $\begin{array}{c}150 \mathrm{~mm} \times 150 \\
\mathrm{~mm} \times 150 \\
\mathrm{~mm}\end{array}$ & 0 Days & 1.5 & 302 & 1163 \\
\cline { 2 - 5 } & 3 Days & 35 & 675 & 1054 \\
\cline { 2 - 5 } & 7 Days & 43 & 765 & 499 \\
\hline
\end{tabular}

A sample of Soil $96 \%$ and Alccofine 4\%.Unconfined compression test is done on the sample after the curing of samples samples. The blocks withstand a Compressive Strength of $1.5 \mathrm{kN} / \mathrm{mm}^{2}, 35 \mathrm{kN} / \mathrm{mm}^{2}, 43 \mathrm{kN} / \mathrm{mm}^{2}$, at 0,3 , and 7 days of curing respectively. Maximum horizontal deformation is $765 \mathrm{~mm}$ at 7 days of curing and maximum vertical deformation is $1163 \mathrm{~mm}$ at 0 days of curing. Minimum horizontal deformation of $302 \mathrm{~mm}$ is at the 0 days of curing. Minimum vertical deformation of 499 is at the 7 days of curing.

Figure 9 indicates that the compressive strength has been increased on the respective days of curing.( $0,3,7$ days).

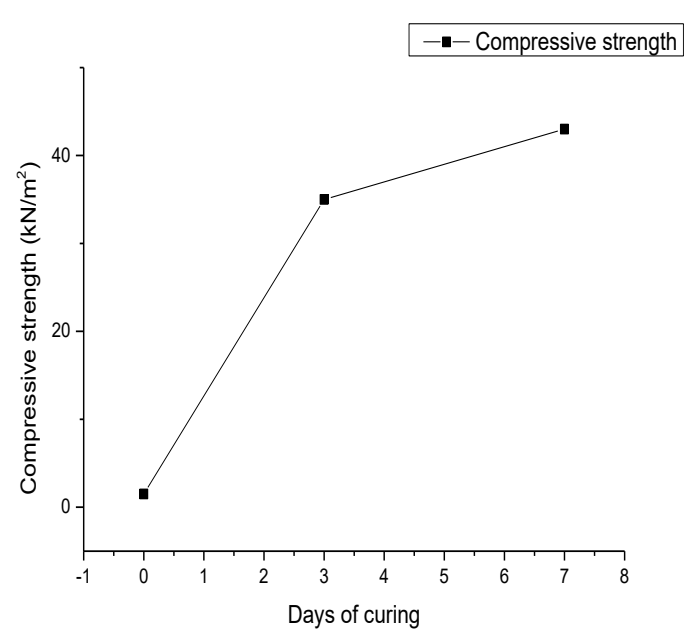

Fig. 9: Number of Days of Curing Versus Compressive Strength For Type 1 Blocks.(Soil 96\%+Alccofine 4\%)

Below graph shows the rise and decrease in horizontal and vertical deformation on the number of curing days. 


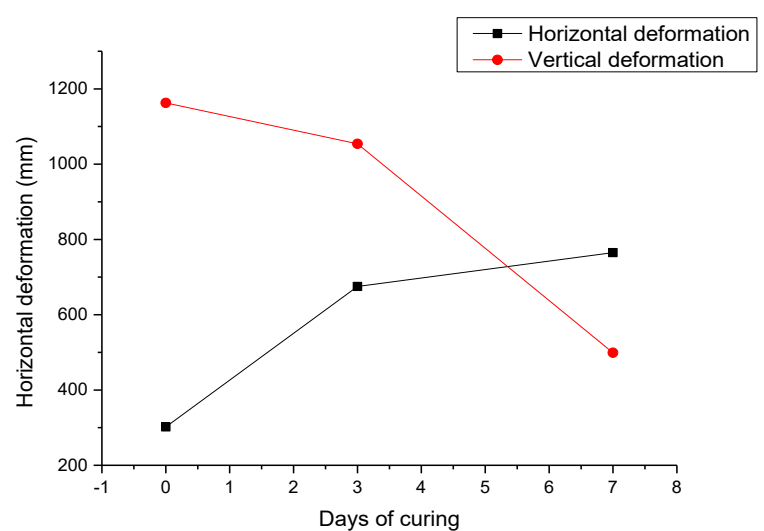

Fig. 10: Number of Days of Curing Versus Deformation For Type 1 Blocks.(Soil 96\%+Alccofine 4\%)

Next graph indicating the increase and decrease of horizontal and vertical deformation on the compressive load applied.

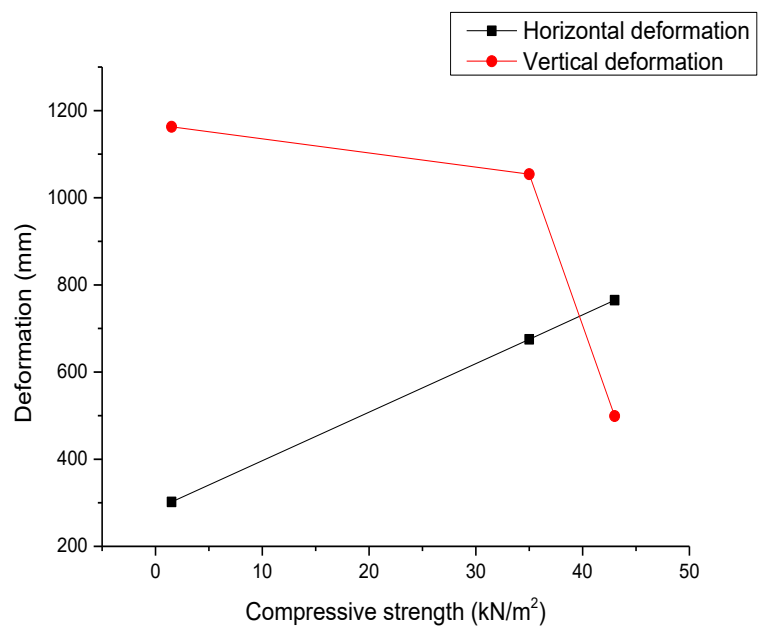

Fig. 11: Compressive Strength Versus DeformationFor Type 1 Blocks.(Soil 96\%+Alccofine 4\%)

Type 2: Soil (97\%) + Sodium meta silicate (3\%)

Table-6: Results Of Unconfinned Compression Test Using Soil $97 \%$ With Sodium Meta Silicate 3\%

\begin{tabular}{|c|c|c|c|c|c|}
\hline $\begin{array}{l}\text { Sl } \\
\text { No }\end{array}$ & $\begin{array}{l}\text { Block } \\
\text { Size }\end{array}$ & $\begin{array}{l}\text { Period of } \\
\text { curing }\end{array}$ & $\begin{array}{l}\text { Compres } \\
\text { sive } \\
\text { Strength } \\
\left(\mathrm{kN} / \mathrm{mm}^{2}\right. \\
)\end{array}$ & $\begin{array}{l}\text { Horizon } \\
\text { tal } \\
\text { Deform } \\
\text { ation } \\
(\mathrm{mm}) \\
\end{array}$ & $\begin{array}{l}\text { Vertic } \\
\text { al } \\
\text { Defor } \\
\text { mation } \\
(\mathrm{mm})\end{array}$ \\
\hline 1 & \multirow{3}{*}{$\begin{array}{c}150 \mathrm{~mm} \times \\
150 \mathrm{~mm} \times \\
150 \mathrm{~mm}\end{array}$} & 0 Days & 4.5 & 368 & 1335 \\
\hline 2 & & 3 Days & 11.5 & 297 & 542 \\
\hline 3 & & 7 Days & 14.5 & 140 & 683 \\
\hline
\end{tabular}

A sample of soil $96 \%$ and sodium meta silicate $3 \%$ is made. Test of unconfined compression test is done on the sample after curing of the samples. The blocks withstand a Compressive Strength of $4.5 \mathrm{kN} / \mathrm{mm}^{2}, 11.5 \mathrm{kN} / \mathrm{mm}^{2}, 14.5$ $\mathrm{kN} / \mathrm{mm}^{2}$, at 0,3 , and 7 days of curing respectively. Maximum horizontal deformation is $368 \mathrm{~mm}$ at 0 days of curing and maximum vertical deformation is $1335 \mathrm{~mm}$ at 0 days of curing. Minimum horizontal deformation of 140 $\mathrm{mm}$ is at the 7 days of curing. Minimum vertical deformation of 542 is at the 3 days of curing.

This graph indicating that the compressive strength has been increased on the respective days of curing.( $0,3,7$ days)

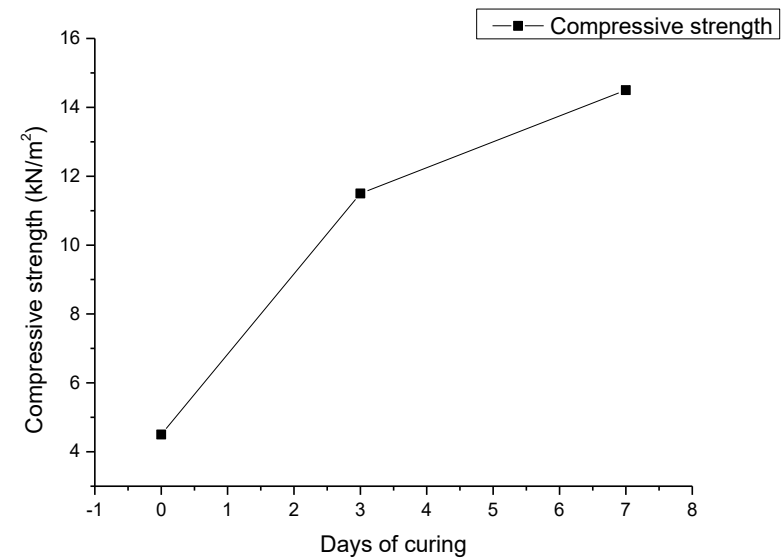

Fig. 12: Number of Days Versus Compressive StrengthFor Type 2 Blocks.(Soil 97\%+Sodium Meta Silicate 3\%)

Below graph shows the rise and decrease in horizontal and vertical deformation on the number of curing days.

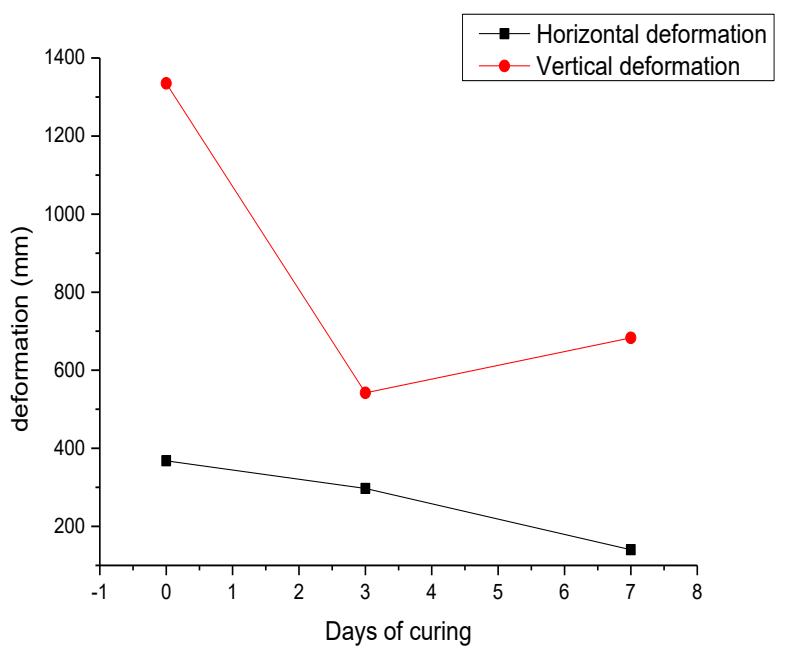

Fig. 13: Number of Days of Curing Versus DeformationFor Type 2 Blocks.(Soil 97\%+Sodium Meta Silicate 3\%)

Below graph indicating the increase and decrease of horizontal and vertical deformation on the compressive load applied. 


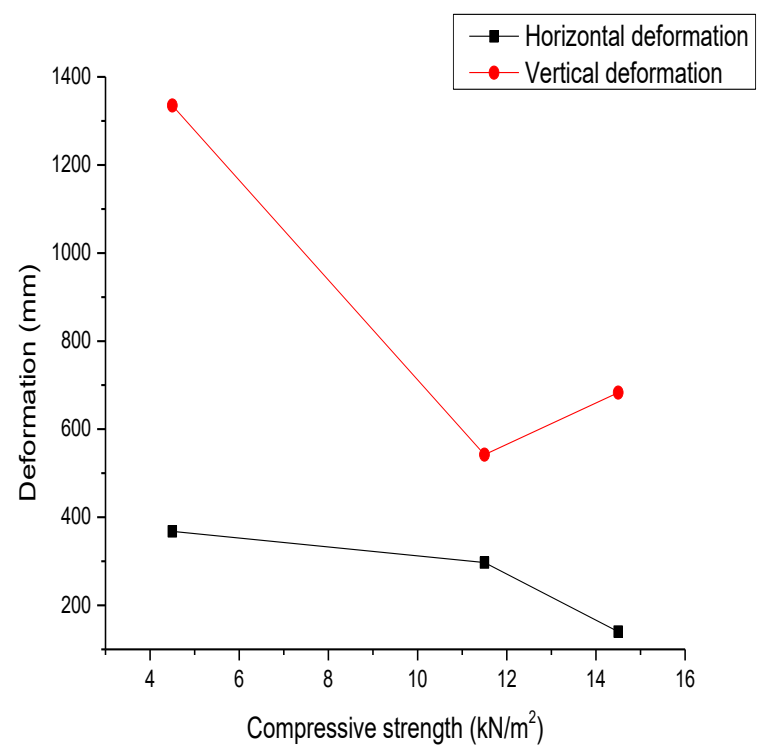

Fig. 14: Compressive Strength Versus DeformationFor Type 2 Blocks.(Soil 96\%+Sodium Meta Silicate 3\%)

Type 3: Soil $(93 \%)+$ Sodium meta silicate $(3 \%)+$ Alccofine (4\%)

Table-7: Results of Unconfinned Compression Test using Soil 93\% with Sodium Meta Silicate 3\% And Alccofine 4\%

\begin{tabular}{|c|c|c|c|c|}
\hline Block & $\begin{array}{c}\text { Period } \\
\text { of } \\
\text { curing }\end{array}$ & $\begin{array}{c}\text { Compressiv } \\
\text { e Strength } \\
\left(\mathrm{kN} / \mathrm{mm}^{2}\right)\end{array}$ & $\begin{array}{c}\text { Horizontal } \\
\text { Deformati } \\
\text { on }(\mathrm{mm})\end{array}$ & $\begin{array}{c}\text { Vertical } \\
\text { Deformati } \\
\text { on }(\mathrm{mm})\end{array}$ \\
\hline $\begin{array}{c}150 \mathrm{~mm} \times \\
150 \mathrm{~mm} \\
\times 150 \\
\mathrm{~mm}\end{array}$ & 0 Days & 2 & 1277 & 1364 \\
\cline { 2 - 5 } & 3 Days & 23.5 & 60 & 1380 \\
\cline { 2 - 5 } & 7 Days & 43.5 & 76 & 725 \\
\hline
\end{tabular}

A sample of soil $93 \%$ with sodium meta silicate $3 \%$ and Alccofine $4 \%$ is made. Test of unconfined compression test is done on the sample after curing of the samples. The blocks withstand a Compressive Strength of $2 \mathrm{kN} / \mathrm{mm}^{2}$, $23.5 \mathrm{kN} / \mathrm{mm}^{2}, 43.5 \mathrm{kN} / \mathrm{mm}^{2}$, at 0,3 , and 7 days of curing respectively. Maximum horizontal deformation at 0 days of curing is $1277 \mathrm{~mm}$ and a cumulative vertical deformation at 3 days of curing is $1380 \mathrm{~mm}$. Minimum horizontal deformation of $60 \mathrm{~mm}$ is the 3-day curing time. The estimated vertical deformation of 5725 occurs within seven days of curing.

This graph indicates that the compressive strength has been increased on the respective days of curing.( $0,3,7$ days).

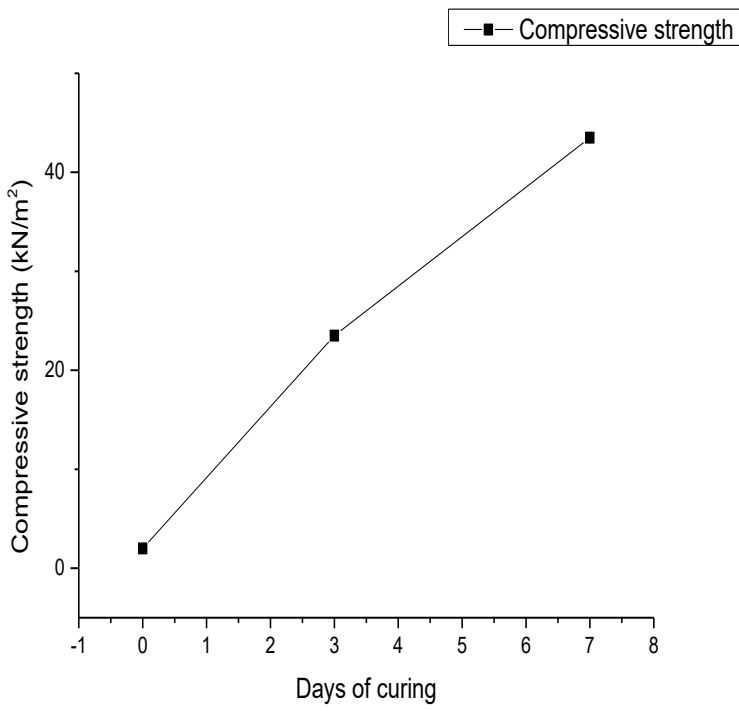

Fig. 15: Number Of Days Versus Compressive Strength for Type 3 Blocks. (Soil93\%+Alccofine4\%+Sodium Meta Silicate $3 \%$ )

Below graph shows the rise and decrease in horizontal and vertical deformation on the number of curing days.

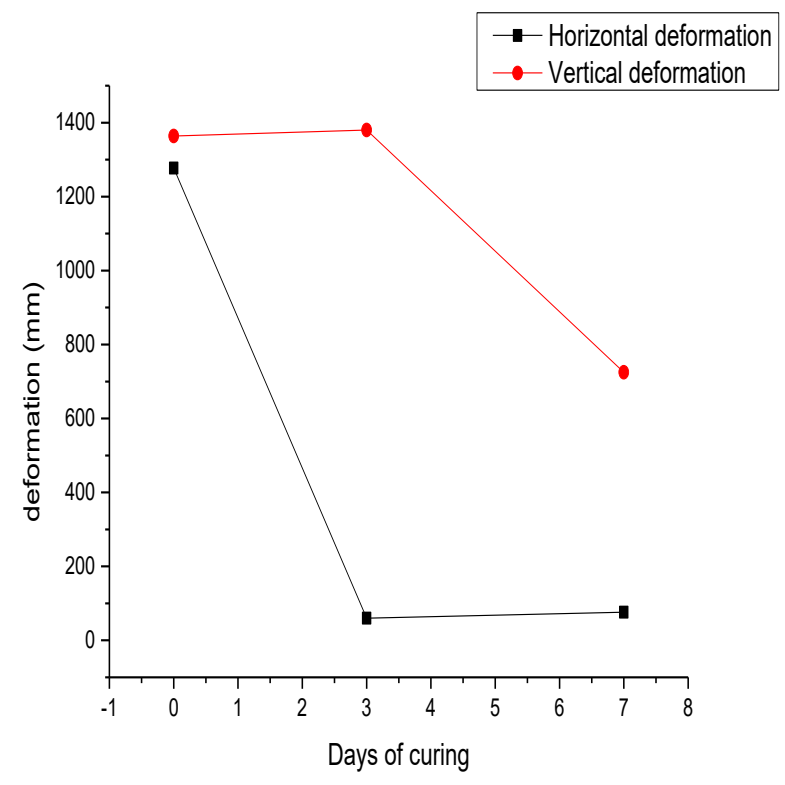

Fig. 16: Number of Days Of Curing Versus DeformationFor Type 3 Blocks.(Soil93\%+Alccofine4\%+Sodium Meta Silicate3\%)

Next graph indicating the increase and decrease of horizontal and vertical deformation on the compressive load applied. 


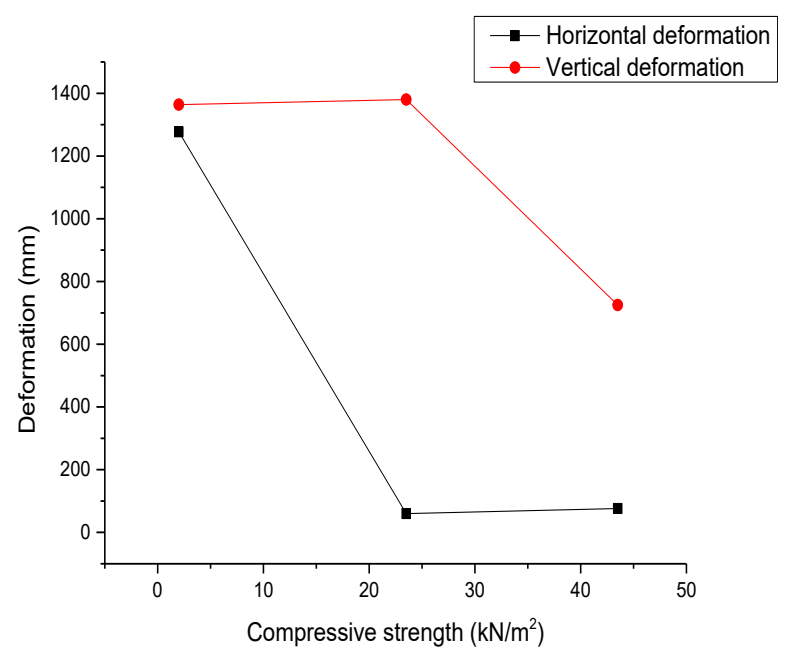

Fig. 17: Compressive Strength versus Deformation for Type 3 Blocks. (Soil93\%+Alccofine4\%+Sodium Meta Silicate3\%)

\section{Conclusion}

- Strength of the SMB was good when both the stabilizers are added to the soil when compared to the blocks that are added with Alccofine and sodium meta silicate.

- Deformation of the SMB is high when both the stabilizers were added. However horizontal deformation was low rather than vertical deformation.

- These Alccofine and sodium meta silicate reduces global warming issues as they can be replaced in the place of fire bricks.

- Alccofine and sodium meta silicate increases the strength of SMB as the days of the curing increases when compared to other conventional bricks.

- Embodied energy of these SMB are very less and its impact on the environment is low.

\section{References}

[1] A. Dhanalakshmi, M. Gokulakrishnan, 'Experimental Investigation on Stabilized Mud Blocks, IJSRD - International Journal for Scientific Research \& Development| Vol. 6, Issue 02, 2018 | ISSN (online): 2321-0613, 4 pages.

[2] Anil Kumar S, Chandra S, Sharath. M Y, Theertharama N, Vasipallivamsikrishnareddy, 'Experimental Study on Behavior of Stabilized Mud Block Using Fly ash and Quarry Dust' International Journal for Research Trends and Innovation (www.ijrti.org) Volume 2, Issue 6 | ISSN: 2456-3315, 6

[3] Jijo James, P. Kasinatha Pandian, K. Deepika, J. ManikandaVenkatesh,V. Manikandan, and P. Manikumaran, 'Cement Stabilized Soil Blocks Admixed with Sugarcane Bagasse Ash' Hindawi Publishing Corporation Journal of Engineering Volume 2016 , Article ID 7940239, 9 pages http://dx.doi.org/10.1155/2016/7940239.

[4] Rakesh D R1, Arpitha V A2, Afaque Ahmed3, Dr S Kavitha4, 'Stabilized Mud Blocks Using Alccofines and GGBS, International Research Journal of Engineering and Technology (IRJET), www.irjet.net, Volume: 06 Issue: 05 | May 2019, 4 pages.

[5] S. Vimala, K .Kumarasamy, 'Studies on The Strength of Stabilized Mud Block Masonry Using Different Mortar Proportions, International Journal of Emerging Technology and Advanced Engineering (www.ijetae.com) (ISSN 2250-2459, ISO 9001:2008 Certified Journal, Volume 4, Issue 4, April 2014), 5 pages.

[6] Vinu Prakash , Amal Raj, Aravind S, Basil Mathew, Sumith V R, Volume 3 (January 2016) 'STUDIES ON STABILIZED MUD BLOCK AS A CONSTRUCTION MATERIAL, International Journal of Innovative Research in Advanced Engineering (IJIRAE) ISSN: 2349-2763 Issue 01,www.ijirae.com, 6 pages. 